\title{
STRATEGI PEMASARAN HOTEL \& HOMESTAY PADA MASA TRANSISI COVID-19 DI KEK-MANDALIKA LOMBOK
}

\author{
Oleh \\ Lalu Mahsar \\ Sekolah Tinggi Pariwisata Mataram \\ Email: lombokmahsar2004@gmail.com
}

\begin{abstract}
Sekarang ini industri pariwisata khususnya sektor akomodasi seperti hotel dan homestay sedang mengalami krisis akibat penyebaran Covid-19. Salah satu destinasi yang juga ikut terdampak akibat Covid-19 adalah KEK Mandalika di Kuta Lombok Tengah. Dampak penyebaran Covid-19 menyebabkan tingkat kunjungan wisatawan baik domestik maupun mancanegara ke KEK Mandalika menurun drastis, termasuk okupansi hotel yang mencapai $30 \%$ dan beberapa hotel sudah mulai menerapkan kebijakan seperti, pengurangan jam kerja dan bahkan PHK. Untuk maksud tersebut, penelitian ini memfokuskan pada: (1) strategi pemosisian (positioning strategy) hotel dan homestay di KEK Mandalika pada masa transisi Covid-19; (2) identifikasi sumber daya hotel dan kapabilitas perusahaan; dan (3) strategi menciptakan kepuasan dan loyalitas pelanggan. tujuan penelitian ini adalah untuk membuat strategi pemosisian hotel dan homestay pada masa transisi Covid-19, mengidentifikasi sumber daya, seperti manusia, keuangan, dan pengalaman perusahaan, kapabilitas perusahaan, seperti relasi atau jejaring yang dibangun, nilai (value) yang dijalankan, dan pemanfaatan teknologi. Tujuan terakhir adalah mengidentifikasi faktor-faktor yang mempengaruhi kepuasan pelanggan. Jenis penelitian adalah kualitatif yang mencoba menganalisis berbagai fenomena kepariwisataan. Penelitian ini berlokasi di beberapa hotel dan homestay di KEK Mandalika dengan pertimbangan bahwa lokasi yang dipersiapkan sebagai tempat diselenggarakannya MotoGP selain karena krisis yang disebabkan Covid-19 yang menyebabkan menurunnya tingkat hunian hotel dan dampak-dampak lainnya. Data primer yang dikumpulkan adalah yang bersumber langsung dari sumber pertama yakni, manager hotel, departemen, seksi, dan staff yang relevan, pemilik homestay, pihak pengembang (manajemen ITDC), masyarakat local di KEK Mandalika, PKL, pemerintah, akademisi, dan media. Data sekunder berupa literatur, artikel, jurnal, serta berita maupun informasi yang relevan dengan strategi pemasaran hotel dan homestay (tingkat hunian hotel, jumlah kamar, jumlah tamu menginap, pendapatan, dll). Teknik pengumpulan data dalam penelitian ini adalah observasi, wawancara mendalam dan dokumentasi. Teknik observasi yang digunakan adalah pengamat sebagai partisipan. Wawancara mendalam (indepth interview) dengan mengajukan beberapa pertanyaan secara mendalam yang berhubungan dengan fokus penelitian. Teknik dokumentasi, untuk mengumpulkan data dari dokumen dan rekaman. "Rekaman" sebagai setiap tulisan/pernyataan yang dipersiapkan oleh tim peneliti dengan tujuan membuktikan adanya suatu peristiwa. Lebih lanjut, data dianalisis dengan content analysis dimana seluruh isi diinterpretasi berdasarkan teks dan konteks. Luarannya adalah publikasi pada jurnal ilmiah terakreditasi dan terdaftarnya HKI. TKT yang diajukan adalah $1-3$.
\end{abstract} Kata Kunci: Strategi, Pemasaran, Hotel Dan Homestay

\section{PENDAHULUAN}

Sekarang ini industri pariwisata khususnya sektor akomodasi seperti hotel dan homestay sedang mengalami krisis akibat penyebaran Covid-19. Salah satu destinasi yang juga ikut terdampak akibat Covid-19 adalah
KEK Mandalika di Kuta Lombok Tengah. Selain sebagai destinasi super prioritas, KEK Mandalika juga sudah ditetapkan sebagai tempat perhelatan MotoGP pada tahun 2021. Hal ini semakin menjadi pusat perhatian stakeholder pariwisata baik pada tingkat 
internasional, nasional maupun lokal. Dampak penyebaran Covid-19 menyebabkan tingkat kunjungan wisatawan baik domestik maupun mancanegara ke KEK Mandalika menurun drastis, termasuk okupansi hotel yang mencapai $30 \%$ dan beberapa hotel sudah mulai menerapkan kebijakan seperti, pengurangan jam kerja dan bahkan PHK. Lebih lanjut, hotel dan homestay yang ada di KEK Mandalika sampai menurunkan harga dari 5\%-10\% dari harga normal dan ada juga yang sampai menurunkan hingga 60\%. Kondisi ini semakin memprihatinkan, namun berbagai upaya manajemen hotel dan homestay terus dilakukan untuk mempertahankan keberlanjutannya.

Untuk mengembalikan situasi dan kondisi menjadi normal kembali khususnya pada sektor perhotelan memang menjadi pekerjaan yang tidak mudah. Namun demikian, upaya untuk memasarkan hotel di masa Covid-19 terus dilakukan. Berbagai permasalahan yang berkaitan dengan strategi pemasaran dan faktor-faktor yang berpengaruh harus menjadi pertimbangan. Pertimbangan seperti, pilihan wisatawan terhadap hotel, faktor peran sosial dan lingkungan yang mempengaruhi keputusan wisatawan, dan perbandingan penawaran yang menjadikan pilihan wisatawan menjadi lebih bernilai. Apabila hotel dapat membuatkan strategi pemasaran yang tepat maka hal tersebut dapat memperbaiki posisi pada pangsa pasar wisata, memberikan penawaran yang lebih baik, memperbaiki kepuasan pelanggan, tingkat hunian kamar dan menciptakan loyalitas pelanggan. Untuk maksud tersebut, penelitian ini memfokuskan pada: (1) strategi pemosisian (positioning strategy) hotel dan homestay di KEK Mandalika pada masa transisi Covid-19; (2) identifikasi sumber daya hotel dan kapabilitas perusahaan; dan (3) strategi menciptakan kepuasan dan loyalitas pelanggan.

Berdasarkan fokus kajian di atas maka tujuan penelitian ini adalah untuk membuat strategi pemosisian hotel dan homestay pada masa transisi Covid-19, mengidentifikasi sumber daya, seperti manusia, keuangan, dan pengalaman perusahaan, kapabilitas perusahaan, seperti relasi atau jejaring yang dibangun, nilai (value) yang dijalankan, dan pemanfaatan teknologi. Tujuan terakhir adalah mengidentifikasi faktor-faktor yang mempengaruhi kepuasan pelanggan. Penelitian ini mendesak untuk segera dilaksanakan mengingat posisi hotel dan homestay pada masa transisi Covid-19 di pasar wisata mengalami pergeseran, sumber daya yang dimiliki juga mengalami perubahan baik dari aspek kuantitas maupun kualitas, dan kepuasan dan loyalitas pelanggan menjadi tantangan tersendiri untuk menciptakannya. Apabila kajian ini tidak dilaksanakan maka dapat berakibat lanjut pada penurunan tingkat hunian kamar, sumber daya perusahaan yang tidak dimanfaatkan dengan baik, keberlanjutan sumber daya manusia, dan hilangnya pelanggan. Skema penelitian adalah inovatif dimana nilai inovasinya terletak pada strategi pemasaran terkini yang disesuaikan dengan kondisi Covid-19.

Namun di balik kabar baik itu itu semua, realitanya ternyata industri ini di NTB sangat rentan akan berbagai isu; salah satunya adalah bencana alam. Bencana alam dapat terjadi di mana saja, kapan saja, dan kepada siapa saja. Terjadi sampai dengan frekuensi bencana itu pun sampai saat ini sulit diprediksi, bisa hanya sekali dalam ratusan tahun, setahun sekali atau hanya pada saat-saat tertentu. Sangat sulit untuk memprediksi di mana bencana alam akan terjadi, untuk berapa lama, dan berapa kuat serta besar dampaknya (Daniels and Daniels, 2003).

Rentetan musibah bencana gempa bumi yang mengguncang provinsi NTB pada periode waktu Juli-Agustus 2018 tahun lalu merupakan fase-fase sulit bagi pelaku bisnis akomodasi/hotel. Musibah bencana terbesar yang dialami oleh hampir seluruh kegiatan kepariwisataan khususnya dunia bisnis perhotelanyaitu musibah Pandemi Covid19 yang mengakibatkan hampir semua aktivitas tidak bisa terlaksana secara maksimal sehingga banyak sekali mengalami kerugian, baik berupa kerugian fisik (infrasrtuktur), psikologis masyarakat (trauma), sampai pada puncaknya yaitu menurunnya aktifitas ekonomi. Khususnya 
bagi bisnis hotel/akomodasi; semua karakteristik kerugian tersebut telah mereka mereka alami; seperti banyaknya bangunan/bagian hotel yang tidak terurus seperti sedia kala atau rusak (infrasturktur), karyawan yang enggan masuk karena trauma dengan adanya Virus Corona ( Covid-19), sampai pada penurunan tingkat okupansi secara drastis oleh sebab pembatalan kunjungan karena kekhawatiran dan ketakutan oleh calon wisatawan atau tamu yang berencana berlibur ataupun memiliki kegiatan khsususnya di NTB karena adanya pandemi Covid-19.

Untuk mendapatkan gambaran yang utuh mengenai strategi pemasaran hotel, maka lokus penelitian program studi tidak hanya sebatas hotel yang ada di kota Mataram, tapi juga hotel yang ada di Yogyakarta, dengan mempertimbangkan Yogyakarta dahulunya juga pernah mengalami bencana yang serupa dengan yang ada di kota Mataram dan hotel di daerah tersebut kami nilai berhasil di dalam mengelola kembali bisnis mereka melalui strategi pemasaran yang tepat. Oleh karena itu, dianggap perlu diangkat ke dalam sebuah penelitian, di mana penelitian ini merupakan Penelitian Kelompok dengan judul Strategi Pemasaran Hotel dan Homestay pada Masa Transisi Covid-19 Di KEK Mandalika Lombok.

\section{Rumusan Masalah}

Berdasarkan uraian latar belakang yang dipaparkan, maka beberapa rumusan masalah pada penelitian ini dirumuskan sebagai berikut:

1. Bagaimana strategi pemasaran internal hotel dan homestay di Kawasan KEK Mandalika Lombok Tengah Nusa Tenggara Barat?

2. Bagaimana strategi pemasaran eksternal hotel dan homestay di Kawasan KEK Mandalika Lombok Tengah Nusa Tenggara Barat?

\section{Batasan Masalah}

Dalam penelitian ini, dibatasi beberapa masalah yang akan diteliti yakni:

1. Untuk strategi pemasaran internal, akan ditinjau dari upaya manajemen beberapa hotel dan homestay di hotel dan homestay di Kawasan KEK Mandalika Lombok Tengah
Nusa Tenggara Barat untuk mengembalikan kepercayaan diri dan kemampuan memasarkan hotel dari para staff pasca covid19.

2. Untuk strategi pemasaran eksternal, akan ditinjau dari upaya manajemen beberapa hotel dan homestay di Kawasan KEK Mandalika Lombok Tengah Nusa Tenggara Barat untuk memasarkan hotel. Sesuai dengan teori marketing mix, maka dalam penelitian ini akan fokus terhadap 3 unsur marketing mix yaitu Product, Promotion, dan Price.

\section{Tujuan Penelitian}

Adapun tujuan penelitian antara lain:

1. Untuk mengetahui strategi pemasaran internal beberapa hotel dan homestay di Kawasan KEK Mandalika Lombok Tengah Nusa Tenggara Barat pasca bencana Covid19.

2. Untuk mengetahui strategi pemasaran eksternal hotel dan homestay di Kawasan KEK Mandalika Lombok Tengah

\section{METODE}

\section{Jenis Penelitian}

Penelitian ini menggunakan metode penelitian kualitatif melalui pendekatan deskriptif analisis. Tim peneliti turun langsung ke lapangan dan mengobservasi, mengamati, dan langsung berinteraksi dengan pihak-pihak yang mendukung terjawabnya rumusan masalah dari penelitian ini.

\subsection{Lokasi Penelitian}

Penelitian ini berlokasi di beberapa hotel dan homestay di Kawasan KEK Mandalika Lombok Tengah Nusa Tenggara Barat pasca bencana Covid karena di dasarkan pada beberapa pertimbangan: dimana lokasi penelitian ini juga mengalami bencana Pandemi (Covid-19) dan merupakan daerah wisata yang menjadi kunjungan favorit wisatawan domestik maupun mancanegara. Selain itu, alasan kami menjadikan kawasan daerah KEK-Mandailka ini karena merupakan lokasi yang telah dipersiapkan sebagai tempat diselenggarakannya kegiatan MotoGP, sehingga tim peneliti ingin mengetahui 
bagaimana cara atau strategi hotel dan homestay dalam mensiasati kondisi pasca musibah Pandemi (Covid-19) untuk meningkatkan hunian hotel atau okupansi mereka sampai saat ini.

\subsection{Sumber Data}

Sumber data adalah segala sesuatu yang dapat memberikan input masukan berupa data dan informasi. Berdasarkan hal tersebut, sumber data dalam penelitian ini kami bedakan menjadi dua, yaitu data primer dan data sekunder. Data primer yaitu data yang dibuat oleh peneliti untuk maksud khusus menyelesaikan permasalahan yang sedang ditanganinya. Data dikumpulkan sendiri oleh peneliti langsung dari sumber pertama atau tempat objek penelitian dilakukan.

Data sekunder yaitu data yang telah dikumpulkan untuk maksud selain menyelesaikan masalah yang sedang dihadapi. Data ini dapat ditemukan dengan cepat. Dalam penelitian ini yang menjadi sumber data sekunder adalah literatur, artikel, jurnal, serta berita maupun informasi dari situs yang ada di internet, berkenaan dengan penelitian yang dilakukan.

\subsection{Teknik Pengumpulan Data}

Teknik pengumpulan data dalam penelitian ini adalah wawancara, observasi serta dokumentasi.

1. Wawancara yaitu percakapan dengan maksud tertentu. Maksud digunakannya wawancara antara lain mengkonstruksi mengenai orang, kejadian, kegiatan organisasi, perasaan, motivasi, tuntutan, kepedulian dan lain-lain, mengkonstruksikan kebulatan-kebulatan demikian yang dialami masa lalu. Pada penelitian ini teknik wawancara yang digunakan peneliti adalah wawancara mendalam (in depth interview) maksudnya peneliti mengajukan beberapa pertanyaan secara mendalam yang berhubungan dengan fokus permasalahan, sehingga data-data yang dibutuhkan dalam penelitian bisa terkumpul secara maksimal. Terkait informan yang nantinya dijadikan sebagai responden terdiri dari pelaku bisnis/pengelola hotel lokus penelitian.

2. Teknik observasi, dalam penelitian kualitatif observasi diklarifikasikan menurut 3 (tiga) cara. Pertama, pengamat bisa bertindak sebagai partisipan atau nonpartisipan. Kedua, observasi dapat dilaksanakan secara terus terang atau penyamaran. Ketiga, observasi yang menyangkut latar penelitian dan dalam penelitian ini menggunakan teknik observasi yang pertama di mana pengamat bertindak sebagai partisipan.

3. Teknik dokumentasi, menggunakan teknik ini untuk mengumpulkan data dari sumber non insani, sumber ini terdiri dari dokumen dan rekaman. "Rekaman" sebagai setiap tulisan/pernyataan yang dipersiapkan oleh tim peneliti dengan tujuan membuktikan adanya suatu peristiwa. Sedangkan "Dokumen" digunakan untuk mengacu atau bukan selain pada rekaman, yakni tidak dipersiapkan secara khusus untuk tujuan tertentu, seperti: surat-surat, buku harian, catatan khusus, foto-foto dan lain sebagainya.

\subsection{Teknik Analisis Data}

Setelah semua data terkumpul, maka langkah selanjutnya adalah pengelolahan dan analisa data. Analisis data ialah proses mencari dan menyusun secara sistematis data yang diperoleh dari hasil wawancara, observasi, dan dokumentasi, dengan cara mengorganisasikan data ke dalam kategori, menjabarkannya kedalam unit-unit, melakukan sintesa, menyusunnya ke dalam pola, memilih mana yang penting dan akan dipelajari, serta membuat kesimpulan sehingga mudah dipahami oleh dirinya sendiri atau orang lain.

Analisis data dalam penelitian ini menggunakan analisis data kualitatif, jadi dalam analisis data selama di lapangan peneliti menggunakan model analisis data interaktif Miles dan Huberman (Miles, Huberman dan Saldana, 2014: 14). Adapun tahap-tahap analisis menjadi tiga langkah, yaitu: 
1. Reduksi data; adalah memilih, merangkum hal yang pokok, memfokuskan pada hal-hal yang penting, dan mencari tema dan polanya. Data yang di reduksi nantinya akan memberi gambaran yang jelas dan mempermudah tim peneliti untuk melakukan pengumpulan data selanjutnya, dan mencarinya bila diperlukan.

2. Penyajian Data; penyajian ini dapat dilakukan dengan pendekatan statistik deskriptif, yaitu menyusun matriks, grafik, gambar, skema, jaringan kerja, teks yang bersifat naratif, tabel dan seterusnya. Dengan menyajikan data, maka akan memudahkan untuk memahami fenomena apa yang sebenarnya terjadi.

3. Menarik Kesimpulan/Verifikasi; proses penarikan kesimpulan awal masih bersifat sementara, belum kuat, terbuka, skeptik, dan bisa saja berubah jika tidak ditemukan bukti-bukti kuat yang mendukung pada tahap pengumpulan data berikutnya. Kesimpulan akhir akan dilakukan setelah pengumpulan data berakhir.

\section{JADWAL}

Tahun ke-1

\begin{tabular}{|c|c|c|c|c|c|c|c|c|c|c|}
\hline \multirow[t]{2}{*}{$\mathrm{No}$} & \multirow[t]{2}{*}{ Nama Kegiatan } & \multicolumn{9}{|c|}{ Minggu } \\
\hline & & 1 & \begin{tabular}{|l|l|}
2 & 3
\end{tabular} & \begin{tabular}{|l|l|}
4 & 5 \\
\end{tabular} & \begin{tabular}{|l|l|}
6 & 7 \\
\end{tabular} & $8 \mid 8$ & 9 & 10 & 11 & 12 \\
\hline 1 & $\begin{array}{l}\text { Tahap Persiapan } \\
\text { - Rapat tim peneliti } \\
\text { - Pembekelan Surveyor } \\
\text { - Pembuatan Instrument }\end{array}$ & $*$ & $*$ & & & & & & & \\
\hline 2 & $\begin{array}{l}\text { Pelaksanaan Kegiatan } \\
\text { - Pengumpulan data } \\
\text { - Analisis Data } \\
\text { - Seminar Hasil } \\
\end{array}$ & & & $* *$ & $*$ & & & & & \\
\hline 3 & $\begin{array}{l}\text { Desimilasi Hasil Penelitian } \\
\text { - Pembuatan draf laporan } \\
\text { - pembuatan draf artikel ilmiah } \\
\text { - Pengajuan HKI }\end{array}$ & & & & & & & & & \\
\hline
\end{tabular}

\subsection{Deskripsi Lokasi Penelitian}

Bencana penyebaran Covid-19 yang dialami Lombok di tahun 2019 memberikan dampak yang sangat luar biasa bagi tingkat okupansi dan juga kunjungan wisatawan domestik maupun luar negeri. Terjadinya pemutusan kontrak kerja secara besarbesaran terjadi hampir di semua hotel yang ada dipulau Lombok khususnya di KEKMandalika ini sehingga membutuhkan tindak lanjut yang serius dari semua elemen masyrakat khususnya bagi para pelaku bisnis pariwisata baik itu hotel maupun homestay yang berada di KEK Mandalika untuk diperbaikan segera, karena jika tidak dilakukan, maka akan mengurangi nilai tangibility nya di benak konsumen. Hal tersebut kemudian kami jadikan dasar di dalam memilih lokasi penelitian; yang pertama adalah beberapa hotel dan homestay yang terdampak bencana Pandemi (Covid-19).

\section{Hotel JM di Kuta}

\section{Gambar 1 Hotel JM di Kuta Lombok}

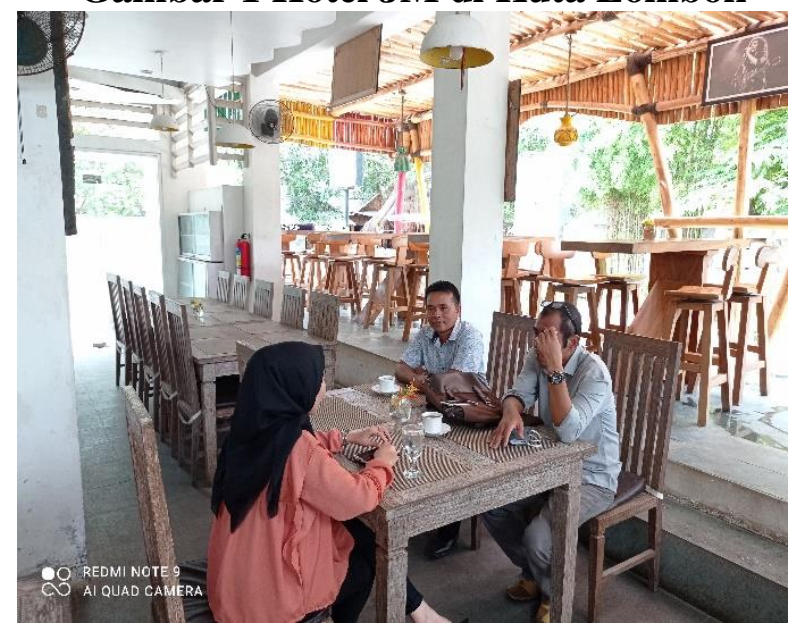

Sumber: Dokumen Peneliti, 2021. 


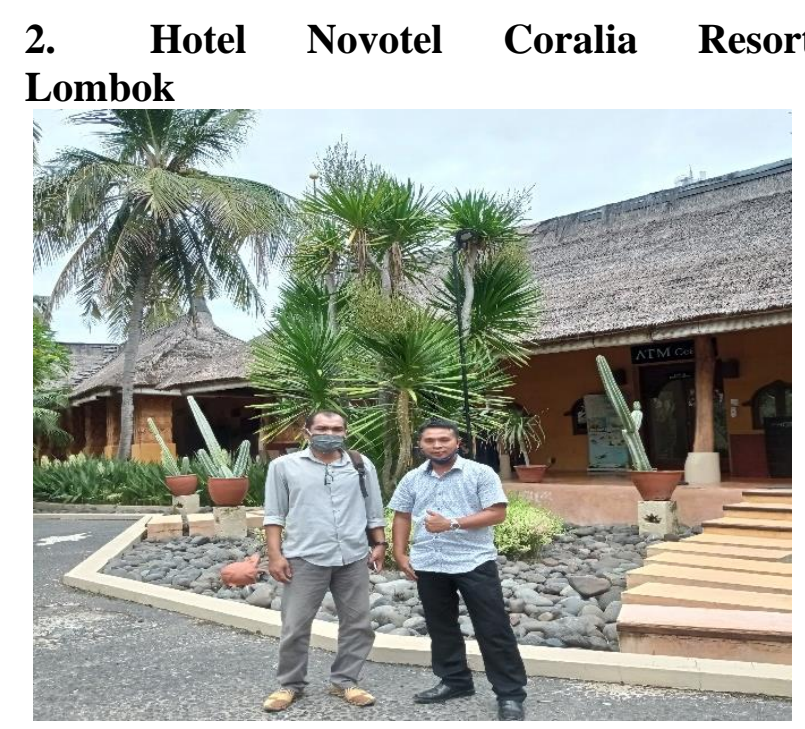

Sumber: Dokumen Peneliti, 2021.

\section{Hotel Kuta Indah Lombok}

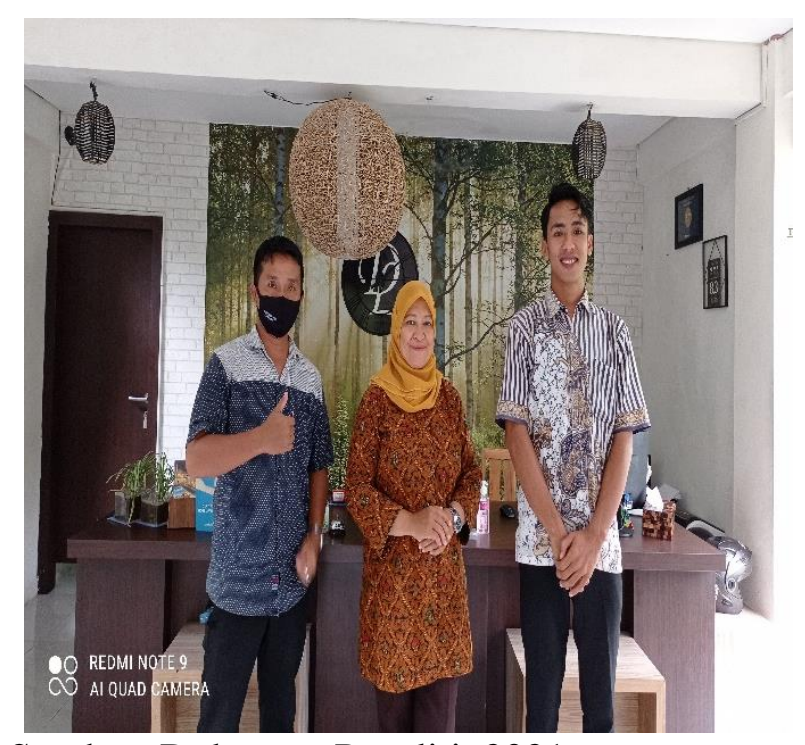

Sumber: Dokumen Peneliti, 2021.

\section{HASIL DAN PEMBAHASAN}

\subsection{Pembahasan Hasil Penelitian}

\subsubsection{Strategi Pemasaran Hotel Pasca Covid-19}

Pasca terjadinya Covid-19 yang melanda dunia lebih-lebih yang dialami semua bisnis pada sector pariwisata khususnya di daerah Kuta dan KEK Mandalika Lombok memberikan dampak yang sangat luar biasa bagi tingkat okupansi dan juga kunjungan wisatawan baik domestik maupun luar negeri. Semua aktivitas khususnya dibidang perhotelan terhenti total yang mengakibatkan hampir semua karywana hotel dirumahkan dengan tidak mendapat kompensasi apapun. Hal ini disebabkan tidak adanya income bagi hotel tersebut baik untuk perawatan gedung maupun bangunan yang rusak karena tidak adanya pemeliharaan signifikan yang disebabkan tidak adanyanya tamu menginap.

Semua fasilitas hotel baik itu kamar tidur, restaurant, kolam sangat membutuhkan perbaikan segera, namun tidak cukup hanya gedung, bangunan atau infrastruktur lainnya, yang paling penting adalah mengembalikan mental dan kondisi psikologis tamu dan karyawan hotel yang trauma dengan kondisi Covid-19 yang telah dialaminya. Pemasaran internal sangat penting artinya bagi perusahaan jasa, terlebih lagi hotel. Hotel dikenal dengan produk jasa dengan tingkat interaksi antara karyawan dan pelanggannya yang cukup tinggi. Dengan kata lain, kualitas jasa pada hotel tidak dapat dipisahkan dari pihak yang menghasilkan jasa tersebut. Sehingga jika hotel ingin mempertahankan kualitas produknya, maka ia sebetulnya harus memperhatikan kualitas karyawannya dalam memberikan pelayanan yaitu dengan selalu menerapkan standar covid dalam setiap kegiatan dan acara untuk seluruh tamu dan karyawan hotel agar terhindar dari virus Covid-19.

Terkait kondisi psikologis karyawan hotel pasca bencana alam yang telah dialaminya, Ketua IHGMA (Indonesia Hotel General Manager Association) Chapter NTB yang dalam wawancara dengan tim peneliti berpendapat:

"Beberapa upaya dan strategi pemasaran yang telah dilakukan diantaranya memberikan edukasi kepada beberapa staff hotel untuk mengikuti kegiatan sertifikasi tehnis guna meningkatkan kompetensi dibidang masingmasing, memberikan harga discount bagi tamu yang mau menginap atau skedar menikmati berenang di kolam. Diharapkan dengan upaya ini pariwisata Lombok bisa pulih kembali, disamping itu juga assessment juga terus dilakukan di sejumlah hotel yang ada. Hal ini untuk memastikan bangunan hotel masih cukup aman untuk dihuni dan mengembalikan kepercayaan wisatawan 
untuk tetap berkunjung serta menginap di hotel-hotel yang ada pasca Covid-19”. (Ernanda, wawancara, 30 Januari 2020).

Strategi pemasaran internal yang dilakukan pasca Covid-19, antara lain:

1. Melakukan program Trauma healing pada karyawan, yang mana program ini dilakukan oleh bagian Human Resources Department. Penyembuhan trauma (trauma healing) dianggap penting agar karyawan dapat menghilangkan kondisi trauma pasca kejadian bencana yang mereka hadapi dan ke depannya diharapkan dapat tetap tenang menghadapi bencana yang mungkin kembali terjadi.

2. Safety briefing untuk karyawan dalam rangka mengantisipasi kejadian atau musibah yang kemungkinan dapat terjadi kembali di masa yang akan datang. Kegiatan dilakukan dengan simulasi yang melibatkan seluruh karyawan hotel. Hal ini dapat diimplementasikan ketika kondisi tingkat okupansi yang rendah sehingga kegiatan tersebut bisa dilaksanakan dengan melibatkan seluruh karyawan.

3. Upgrade knowledge kepada karyawan tentang kekuatan dan struktur bangunan hotel yang kokoh dan masih aman dengan penilaian atau sertifikasi dari Dinas PUPR. Hal ini dilakukan kepada karyawan, agar karyawan bisa menyampaikan tentang kekuatan dan kelayakan bangunan hotel kepada tamu yang menginap dan calon konsumen atau masyarakat luas.

4. Menghimbau kepada seluruh karyawan agar tidak mempublikasikan atau mengkomunikasikan hal-hal yang berkaitan dengan kondisi hotel yang mengalami kerusakan fisik pasca bencana, baik di aplikasi percakapan maupun sosial media yang mereka miliki.

5. Melakukan upaya peningkatan kerjasama dan kesadaran kolektif seluruh karyawan untuk melakukan penyebaran berita maupun konten positif terkait hotel tempat mereka bekerja dengan sekaligus memberikan sanksi apabila terdapat karyawa yang melanggar karena memposting hal-hal yang kurang tepat di aplikasi percakapan maupun media sosial yang mereka miliki.

Terkait dengan strategi penetapan harga yang diterapkan di Hotel dan Homestay Kuta Lombok ada perbedaan strategi pemasaran yang diterapkan dengan menurunkan harga sampai dengan $60 \%$ dari harga semula Rp. 1.800.000 untuk rate yang paling tinggi turun menjadi Rp. 450.000,-. Imbas dari penurunan harga yang turun $60 \%$, pendapatan hotel menurun dan tidak ada insentif bagi karyawan. Di samping itu juga, salah satu bentuk strategi penurunan harga yang dilakukan yaitu pihak hotel memberikan pelayanan khusus dan harga coorperate dengan relawan ketika menginap.

\section{i. Positioning Strategy}

Berdasarkan haisl pengamatan dan wawancara dengan pihak hotel yang tergabung dalam MHA (Mandalika Hotel Association) diketahui bahwa untuk strategi pemasaran dengan menerapkan strategi posisi (positioning strategy) ada 2 hal yang menjadi pertimbangan para manager hotel yakni, aspek pesaing (competitor). Diakui bahwa sebelum pandemic Covid-19 pesaing utama hotel-hotel yang tergabung dalam MHA adalah hotel yang secara karakteristik lokasi sama yakni, hotel resort baik yang berada di Senggigi (Sheraton, Holiday Resort, Killa Senggigi, Svarga Resort, The Jayakarta), di KLU (The Oberoi, Villa Ombak dan Ombak Sunset).

Aspek kedua yakni, re-branding hotel juga menjadi perhatian semua manager hotel akibat pandemik Covid-19. Diperlukan adanya penyesuaian-penyesuain dengan kondisi terkini (new normal). Kesadaran dari pengelola juga tampak bahwa material promosi dan pemasaran sekarang ini harus banyak menampilkan dan menunjukkan kondisi destinasi dengan konsep Cleanliness, Healthy, Safety, Environment (CHSE) di semua hotel dengan penerapan protokol yang ketat. Berdasarkan hasil observasi dan wawancaran dengan Sales Marketing Manager JM Hotel Kuta yang 
sekaligus sebagai Sekretaris MHA menyatakan bahwa semua hotel yang tergabung dalam MHA rata-rata sudah menerapkan CHSE dengan menerapkan protokol kesehatan seperti, memeriksa suhu badan semua tamu yang masuk dengan thermogun, menyediakan handsantizer, tempat mencuci tangan, pemeriksaan masker, dan penerapan social distancing baik di lobby hotel maupun di ruangan yang digunakan untuk event tertentu.

Dengan demikian, konsep positioning strategi hotel dan homestay yang berada di KEK Mandalika harus mempertimbangkan aspek CHSE sebagai salah satu isi atau content dalam mempromosikan dan memasarkan produk di era pandemic Covid-19. Jika hal ini dapat dilakukan maka keberadaan hotel di KEK Mandalika pada masa krisis seperti ini dapat berkelanjutan walaupun kondisinya tidak seperti sebelumnya. Namun demikian, strategi dengan mengetahui posisi perusahaan pada pasar wisata menjadi sangat penting bagi para manager hotel.

\section{ii. Resources Strategy}

Strategi dengan memanfaatkan sumber daya (resources strategy) hotel yang tergabung dalam MHA juga tampak jelas dilakukan. Ada 4 aspek penting yang dilakukan untuk dapat mengimplementasikan strategi ini yakni, aspek fisik, keuangan, pengalaman, dan nilai). Misalnya dari aspek fisik, sebagian besar hotel memanfaatkan produk fisiknya (kamar, kolam renang, ball room) dengan memasarkannya pada pasar domestik dengan harga yang murah dan bahkan diberikan potongan harga hingga $50 \%$. Strategi ini juga cukup efektif walaupun daya beli wisatawan domestik mengalami penurunan akibat pandemik Covid-19. Sasaran pemasaran yang ditargetkan beberapa hotel adalah anak-anak sekolah baik yang ada di SD, SMP, maupun SMA, kemudian para pemerintah daerah agar pertemuannya diselenggarakan di hotel.

Aspek kedua, keuangan. Disadari bahwa kondisi keuangan hotel di MHA rata-rata sama yakni pendapatan menurun drastis. Setidaknya dan bahkan masih kurang walaupun hanya untuk membiayai kebutuhan untuk pemeliharaan. MHA juga telah melakukan pengetatan finansial dengan cara mengurangi beban pengeluaran hotel misalnya, menerapkan kebijakan merumahkan karyawan, masuk dengan system shift, dan bahkan kondisi yang memaksa harus dilakukan PHK. Strategi pemanfaatan keuangan juga berlaku untuk promosi dan pemasaran bagi hotel-hotel besar yang memiliki jaringan internasional (international chain hotel) seperti Novotel yang memanfaatkan konsep co-branding, copromotion, co-marketing dengan alasan efektifitas dan efisiensi biaya, waktu, dan tenaga.

Aspek dengan mengandalkan pengalaman (experiential) hotel yang tergabung dalam MHA kaitannya dengan strategi pemasaran pasca Covid-19 ini memang belum terasa karena krisis yang diakibatkan pandemik Covid-19 baru pertama kali dirasakan. Akibatnya semua hotel terpuruk baik dari sisi tamu yang menginap, okupansi, pendapatan maupun reputasi dan citra perusahaan. Bagusnya hotel dengan jaringan internasional yang sudah memiliki pengalaman dalam memulihkan akibat pandemik dapat dijadikan sebagai rujukan. Sebagai contoh, Novotel Lombok yang terlihat masih bertahan hingga saat ini. Walaupun juga kebijakan terhadap pengurangan karyawan dilakukan.

Aspek nilai yang dijalankan (value sharing) bagi MHA di KEK Mandalika sebagian besar adalah hotel resort sehingga citra dan reputasi hotel semuanya berasal dari keindahan alam, kehidupan masyarakat lokal, dan keramahtamahan penduduk. Bahasa promosi dan pemasaran yang muncul di media baik online maupun yang offline juga merepresentasikan keindahan alam Lombok Selatan. Inilah value sharing yang dapat ditunjukkan MHA kepada pangsa pasar atau pelanggan. Dengan demikian, tamu-tamu yang menginap di hotel KEK Mandalika semuanya memiliki karakteristik yang sama yakni, sebagai tamu yang menikmati liburan di tempat yang jauh dari keramaian. Dalam hal ini, para manager hotel juga dituntut untuk menjadi 
seorang holiday maker yang professional di era pandemik sekarang ini.

\section{iii. Capability Strategy}

Strategi berikutnya yang juga tidak kalah pentingnya adalah jejaring dan respon terhadap teknologi dan informasi. Strategi ini sangat bermanfaat dalam memastikan keberlanjutan hotel di era pandemic seperti sekarang ini. Networking atau jejaring dapat memainkan peran penting dalam promosi dan juga pemasaran. Hal ini dapat menghemat biaya, waktu, dan tenaga. Aspek efektifitas dan efisiensi menjadi tujuan akhir dari strategi memanfaatkan jaringan hotel. Pada konteks ini, MHA dapat memaksimalkan peran dari hotelhotel besar dalam mempromosikan hotel-hotel kecil dengan konsep co-marketing dan cobranding.

Strategi jejaring berkaitan erat dengan kemampuan untuk merespon kemajuan teknologi dan informasi bagi hotel. MHA dalam kasus ini harus segera mengadaptasikan system baik dalam hal memromosikan dan memasarkan produk maupun pelayanan semuanya berbasis pada TI. Jika tidak maka posisi MHA dapat semakin memburuk di era pandemic sekarang ini. Tren pelanggan pasca Covid-19 dan di masa mendatang semuanya mengarah pada efektifitas dan efisiensi pengantaran produk dan pelayanan yang terukur. Istilahnya harus mampu memastikan produk dan pelayanan terantarkan dengan baik (must deliver).

Dengan demikian, strategi pemasraan hotel pasca Covid-19 idealnya harus relevan satu dengan yang lainnya. Antara strategi positioning, resources, dan capability harus berada dalam satu arah dan program yang sama dalam konteks MHA di KEK Mandalika. Kunci suksesnya ada pada komitmen bersama para manager hotel untuk mempertahankan keberlanjutan usaha di era pandemik.

\section{PENUTUP}

\section{Kesimpulan}

Dari hasil dan pembahasan mengenai strategi pemasaran hotel dan homestay pasca Covid-19 dapat disimpulkan sebagai berikut.
Strategi pemasaran internal Hotel \& Homestay pasca Covid-19 di KEK- Mandalika dilakukan melalui program trauma healing pada karyawan (1); safety briefing untuk karyawan (2); upgrade knowledge kepada karyawan tentang kekuatan dan struktur bangunan hotel yang kokoh dan masih aman (3); menghimbau kepada seluruh karyawan agar tidak mempublikasikan atau mengkomunikasikan hal-hal yang berkaitan dengan kondisi hotel pasca Covid-19 (4); mendorong karyawan melakukan pemberitaan yang positif ke media massa maupun media sosial yang mereka miliki (5); melakukan upaya peningkatan kerjasama dan kesadaran kolektif seluruh karyawan untuk melakukan penyebaran berita maupun content positif terkait hotel tempat mereka bekerja dengan sekaligus memberikan sanksi apabila terdapat karyawa yang melanggar karena memposting hal- hal yang kurang tepat di aplikasi percakapan maupun media sosial yang mereka miliki. Strategi pemasaran eksternal hotel dengan memanfaatkan media terbarukan saat ini; baik dari segi produk, harga, dan promosi, merupakan tantangan yang harus segera direspon dengan cepat dan tepat.

Strategi pemasaran lainnya yang dianggap efektif dan efisien untuk keberlanjutan MHA di KEK Mandalika pasca Covid-19 adalah menerapkan 3 strategi utama yakni, positioning, resources, dan capability strategies. Strategi pertama berkaitan dengan pemahaman terhadap posisi pesaing dan perubahan citra hotel dengan konsep rebranding. Strategi kedua, dengan memanfaatkan aspek fisik hotel sebagai bahan promosi dan pemasaran, memberlakukan pengetatan keuangan, pengalaman masa lalu, dan nilai yang dijalankan (value sharing). Strategi ketiga adalah dengan menerapkan kemampuan (capability) dari MHA dengan memfokuskan pada jejaring (networking) dan respon terhadap TI.

Saran

Agar pemasaran hotel yang tergabung dalam MHA tetap berkelanjutan di masa pandemic Covid-19 maka saran yang ditawarkan adalah: 
1. MHA sebagai asosiasi atau organisasi harus memperkuat kapasitas kelembagaan dengan cara memanfaatkan TI sebagai basis dalam memberikan pelayanan, mempromosikan dan memasarkan produk hotel.

2. Memperkuat jejaring hotel yang berada dalam MHA

3. Melakukan promosi dan pemasaran dan pencitraan secara bersama-sama dengan konsep co-branding, co-marketing.

\section{DAFTAR PUSTAKA}

[1] Alma, Buchari. 2010. Manajemen Pemasaran dan Pemasaran Jasa.

[2] Bandung: Alfabeta

[3] Assauri, Sofjan. 2013. Manajemen Pemasaran. Jakarta: Rajawali Pers.

[4] Budi, Sulistino, Ari. 2010. "Pengaruh Kualitas Pelayanan, Fasilitas, dan Lokasi terhadap Keputusan Menginap Tamu Hotel Srondol Indah Semarang”, Fakultas Ekonomi Universitas Dipenogoro Medan.

[5] Haryono. 2015. Dashyatnya Pengelolaan Sumber Daya Manusia Dalam Bisnis Perhotelan. Jakarta: Fakultas Ekonomi Universitas Indonesia.

[6] Hurriyati, Ratih. 2005. Bauran Pemasaran dan Loyalitas Konsumen. Bandung: Alfabeta.

[7] Kasmir, 2014. Kewirausahaan. Jakarta: PT. RajaGrafindo Persada.

[8] Kotler, Philip. 2005. Manajemen Pemasaran Jilid 1 dan 2. Jakarta: PT Indeks Kelompok Gramedia.

[9] Kotler dan Keller, 2012, Marketing Management Edisi 14, Global Edition. Pearson Prentice Hall.

[10] Kotler, Philip dan Gary Armstrong. 2012. Dasar-Dasar Pemasaran. Jilid 1. Alih Bahasa: Alexander Sindoro.

Jakarta. Penerbit Prenhallindo

[11] Kotler, Philip. 2012. Marketing Reaserch. Edisi Kedua. Yogyakarta. Penerbit Koputindo
[12] Rangkuti, Freddy. 2014. Analisis SWOT: Teknik Membedah Kasus Bisnis. Jakarta: PT Gramedia Pustaka Utama

[13] Meskardo, Sembiring. 2015. Omset Berlipat dari Bisnis Hotel, Tur, dan Travel. Jakarta: Cermelang Publishing.

[14] Sugiarto, Endar. 2009. Hotel Front Office Administraction (Administrasi Kantor Depan Hotel). Jakarta: PT. Gramedia Pustaka Utama,

[15] Sulistiyono, Agus. 2008. Manajemen Penyelenggara Hotel, Cetakan ke 6. Bandung: Alfebeta.

[16] Sumarni, Murti \& John Soeprihanto. 2010. Pengantar Bisnis (Dasar-dasar Ekonomi Perusahaan) Edisi ke 5. Yogyakarta: Liberty Yogyakarta

[17] Sumarsono, Dicky. 2014. Dahsyatnya Bisnis Hotel Di Indonesia. Jakarta: PT. Gramedia Pustaka Utama.

[18] Suparyanto \& Rosad. 2015. Manajemen Pemasaran. Bogor: IN MEDIA

[19] Tjiptono, Fandi. 2008. Strategi Pemasaran Edisi Ke 3. Yogyakarta: Andi Office. 